Bond University ePublications@bond

Sports Law eJournal

Faculty of Law

$11-4-2011$

\title{
Dangerous Sports and Obvious Risks - Anyone For Cricket?
}

Jim Corkery

Bond University

Follow this and additional works at: http://epublications.bond.edu.au/slej

Part of the Entertainment, Arts, and Sports Law Commons

\section{Recommended Citation}

Jim Corkery. (2011) "Dangerous Sports and Obvious Risks - Anyone For Cricket?" ,, .

http://epublications.bond.edu.au/slej/12

This Journal Article is brought to you by the Faculty of Law at ePublications@bond. It has been accepted for inclusion in Sports Law eJournal by an authorized administrator of ePublications@bond. For more information, please contact Bond University's Repository Coordinator. 


\title{
Dangerous Sports and Obvious Risks - Anyone For Cricket?
}

\begin{abstract}
Dangerous sports contribute noble attributes to society and promote social cohesion. Cricket is a sport in point. It is capable, too, of being a dangerous sport, with athletes hurling the hard cricket ball at speeds in excess of $180 \mathrm{kph}$ - or $100 \mathrm{mph}$. So cricket can be hazardous: cricket can injure. Should the law regulate for every risky situation and underwrite every recreational injury? Or should society tolerate, perhaps encourage, dangerous sports, because their benefits outweigh the costs?
\end{abstract}

\section{Keywords}

cricket, dangerous recreational activity, obvious risk, Civil Liability Act (Qld)

\section{Disciplines}

Entertainment, Arts, and Sports Law 


\title{
DANGEROUS SPORTS AND OBVIOUS RISKS - ANYONE FOR CRICKET?
}

\author{
JIM CORKERY ${ }^{1}$
}

\begin{abstract}
Dangerous sports contribute noble attributes to society and promote social cohesion. Cricket is a sport in point. It is capable, too, of being a dangerous sport, with athletes hurling the hard cricket ball at speeds in excess of $180 \mathrm{kph}$ - or $100 \mathrm{mph}$. So cricket can be hazardous: cricket can injure. Should the law regulate for every risky situation and underwrite every recreational injury? Or should society tolerate, perhaps encourage, dangerous sports, because their benefits outweigh the costs?
\end{abstract}

The world has two great 'bat and ball' games: baseball and cricket. Both are English folk games in origin. Both have spread throughout the world - cricket following English influence and baseball following American influence. Cricket has many more players and fans, mainly because it spread to the populous Indian subcontinent.

Both games can be dangerous. Those who faced Australian cricket fast bowler Jeff Thomson with only a slim wooden bat in hand say that he was the fastest of them all. He was more than menacing. Tongue in cheek, Thomson made world news when he said in a television interview before a cricket Test: 'I enjoy hitting a batsman more than getting him out. I like to see blood on the pitch'.

Thomson's wicketkeeper Rod Marsh - who had to catch the ball should it pass the batsman - claimed that 'Thommo' at his peak was bowling at $180 \mathrm{kph} \mathrm{-} 20 \mathrm{~km}$ faster than the next fastest bowler! This human catapult was at the end of his career before they were able to measure his speed electronically. Even then, by conventional radar, Thomson was recorded at $160.58 \mathrm{kph}$. That is just a shade under $100 \mathrm{mph}$. Controversial Pakistani paceman Shoaib Akhtar was timed at $161.3 \mathrm{kph}$ in the 2003 Cricket World Cup.

Don Bradman, the greatest batsman of all time, faced a dynamic young Aboriginal Australian fast bowler, whose shoulder strength had been honed as a champion boomerang thrower. Off a short run, Eddie Gilbert hurled down five thunderbolts that Bradman described as the fastest deliveries he ever faced. ${ }^{2}$ One knocked the bat out of the great batsman's hands. Gilbert then dismissed Bradman, for a duck. Gilbert's biographer, Ken Edwards, recalls a favourite legend about the Aboriginal speed merchant:

he bowled so quickly in one match that the ball went through the wicket-keeper, through the coat held out by the long-stop, through a picket fence on the boundary and killed the butcher's dog on the other side of the fence. ${ }^{3}$

In baseball, the pitchers can make the ball go just as fast - by throwing rather than straight-arm bowling. The fastest baseball pitch is believed to be $103 \mathrm{mph}$ by Mark Wohlers in 1995 in a training camp. Nolan Ryan's fastball was clocked for the Guinness Book of World Records at 100.9 miles per hour in a 1974 game.

1 Professor of Law, Bond University. The author gratefully acknowledges the considerable assistance provided by Katherine Mansted in researching and writing this article. It was also delivered as a paper at the $21^{S T}$ CENTURY COMMERCIAL LAW COLLOQUIUM of the Centre for Commercial Law, Bond University, 13-14 August 2010 held at the University of South Australia, Adelaide Hilton Hotel and Magill Estate, Adelaide.

2 ABC Radio National, 'The Whirlwind Ebony Trundler', The Sports Factor, 11 October 2002 (Donald Bradman).

3 ABC Radio National, 'The Whirlwind Ebony Trundler', The Sports Factor, 11 October 2002 (Ken Edwards). 


\section{CRICKET IS DANGEROUS?}

'Frederick, Prince of Wales, was killed by a cricket ball. This brought his son, George III, early to the throne. And it was George III's clumsy handling which caused the American War of Independence and the secession of the United States from the British Empire a couple of centuries ago.'

Cricket is a game of respect, rule books and elaborate fairness. The United States' founding father John Adams was considering what title to call the US chief executive. Adams said that the most respected man in a New England village was the 'president' of the cricket club. So the US chose the term president. Cricket is famous for the number of fairness metaphors attached to the game. 'It's not cricket' means universally that fair play is absent. If you 'play with a straight bat' or get 'hit for six' or are 'bowled over', you are talking cricket. So too if you are 'on a sticky wicket'. But not all about the game is honourable or peaceful.

In 1751 Frederick Lewis Prince of Wales died allegedly of complications after a cricket ball strike. (Not so. Although he was hit in the head by a ball, the true cause of his death was a burst abscess in a lung.) Cricket can be lethal. A young cricketer died after being hit in the chest by a ball in Manchester in 2005. A cricket umpire died in 2009 in Wales after being hit on the head by a ball thrown by a fielder.4 Several top level cricketers have died in action from head wounds or from a hit about the heart, as have amateur players.5 In 2010 a thirteen-year-old South African died after a cricket ball strike to his chest. Some players have lost eyes, fingers, toes and teeth, to say nothing of testicles.

Only of late have cricketers worn protective headgear - although leg pads and gloves have always been in the game. Usually the injuries are suffered while batting, although sometimes close-in fielders can sustain serious blows.6 George Summers died at the London home of cricket at Lord's in 1870 when hit on the head by a short-pitched delivery. He appeared to recover and went home on the train, but succumbed four days later. The batsman who followed Summers to the crease that day had wrapped a towel around his head in protest at the short-pitching bowler, who never bowled fast again after the incident.

The potential for injury on the cricket pitch has ignited political controversy. A cable from the Australian Cricket Board to the English Cricket Board in 1933 reads:

Bodyline bowling has assumed such proportions as to menace the best interests of the game... This is causing intensely bitter feeling between the players, as well as injury. In our opinion it is unsportsmanlike. Unless stopped at once it is likely to upset the friendly relations existing between Australia and England. ${ }^{7}$

4 David Wilkes, 'Cricket Umpire, 72, Killed as Ball Thrown by Fielder Hits Him on the Head', Daily Mail (online), 6 July 2009 <http://www.dailymail.co.uk/news/article-1197617/Cricket-umpire-72-killed-ball-thrownmatch.html>.

$5 \quad$ Abdul Aziz, Karachi wicket-keeper, died after being hit over the heart in the 1958-9 Quaid-e-Azam Trophy final; Ian Folley was batting for Whitehaven in 1993 when he was hit underneath the eye and died shortly after; British Flight Sergeant John Willis died in 2002 from being hit on the head at a match between two air force bases.

6 For example, Indian cricketer Raman Lamba was killed at a club match in Dhaka in 1998 after being hit in the head while fielding without a helmet.

7 Cable from the Australian Cricket Board to the MCC (English Cricket Board, London) 1932-3 Ashes Series, reproduced in Anthony Bateman, Cricket, Literature and Culture: Symbolising the Nation, Destabilising Empire (Ashgate Publishing, 2009) 149. 
Sometimes cricket injuries have led to court actions. Mainly, the court actions concerned the damage caused by the hard ball - to players, umpires, spectators and, occasionally, to the public.

\section{OFF THE PITCH; INTO THE COURT}

Cricket-related injuries have featured in three significant negligence cases in England and Australia. Based on the Biblical command to 'love thy neighbour', the central idea of the negligence tort is that people must exercise a reasonable level of care by taking steps to prevent harm they might foreseeably cause to others.

\section{Bolton v Stone}

In Bolton $v$ Stone, ${ }^{8}$ a surprised Bessie Stone was standing on the pavement outside her garden gate when she was struck by a ball hit for six out of the Cheetham Cricket Club ground. The ball soared over the cricket ground's fence, flew across the road, and hit Miss Stone. She brought an action in negligence against the Club for not taking steps to avoid the danger of a ball being hit out of the ground. But, said the Court, balls were hit outside of the cricket grounds on only rare occasions. Lord Porter noted, 'I think six were proved in twenty-eight years-and it is true that a repetition might at some time be anticipated. But its happening would be a very exceptional circumstance, the road was obviously not greatly frequented and no previous accident had occurred'.$^{9}$

Lord Oaksey added: 'the standard of care in the law of negligence is the standard of an ordinarily careful man, but in my opinion an ordinarily careful man does not take precautions against every foreseeable risk'. ${ }^{10}$ His Lordship recognised that 'cricket has been played for about ninety years on the ground in question and no ball has been proved to have struck anyone on the highways near the ground until the respondent was struck'.11

The Court held that the defendant was not liable. The probability of a ball causing injury was so slight that a reasonable person would not think taking further precautions other than the erection of the fence would be required. Miss Stone's action in negligence failed. She received no compensation for her injuries.

\section{Miller v Jackson}

The famous Lord Denning displayed obvious liking for cricket in Miller $v$ Jackson: ${ }^{12}$ 'In summertime village cricket is the delight of everyone. Nearly every village has its own cricket field where the young men play and the old men watch'. ${ }^{13}$ In that case, the Court of Appeal considered a cricket ground situated in the village of Lintz in an area which was becoming increasingly urbanised. With lusty hitting during games, a number of cricket balls escaped the confines of the cricket ground into the gardens of neighbouring houses. The Court considered whether the defendant (the chairman of a local cricket club) was liable in nuisance or negligence when sixes were hit over the boundary and onto the property of the plaintiffs, Mr and Mrs Miller.

\footnotetext{
$8 \quad$ [1951] AC 850.

9 Bolton $v$ Stone [1951] AC 850, 859 (Lord Porter).

$10 \quad$ Ibid 863 (Lord Oaksey).

11 Ibid.

12 [1977] EWCA Civ 6.

13 Miller v Jackson [1977] EWCA Civ 6.
} 
The Court ruled that the use of this ground for playing cricket was a reasonable use of the land. But the Court had to:

strike a fair balance between the right of the plaintiffs to have quiet enjoyment of their house and garden without exposure to cricket balls occasionally falling like thunderbolts from the heavens, and the opportunity of the inhabitants of the village in which they live to continue to enjoy the manly sport which constitutes a summer recreation for adults and young persons. ${ }^{14}$

While the Court decided not to issue an injunction to stop the cricket, it ruled that every instance of a ball coming over the fence was negligence and the landing of balls in the neighbours' land was actionable nuisance. The Millers were awarded damages.

\section{Woods v Multi-Sport Holdings Pty Ltd}

Australia's most senior sports law case reaffirmed the right to sport without undue risk of legal suit for injuries caused in the pursuit of sport. In Woods $v$ Multi-Sport Holdings Pty Ltd 15 the game was indoor cricket. The ball used is similar in size and weight to an outdoor cricket ball. Not as hard, it is nonetheless an object that can cause damage. Gleeson CJ summarises:

While he was batting, [Mr Woods] received a full toss, and attempted a pull shot. He failed to connect properly, and this caused the ball to ricochet off his bat and hit him in the right eye. As a result, he lost the sight of that eye. ${ }^{16}$

The existence of a duty of care was not disputed. Multi-Sport, as organiser and controller of the games played at its facility, had a duty to take reasonable care of? players of indoor cricket. But what was the content of this duty and had it been breached here?

The case centred on two issues. Should Multi-Sport have provided helmets; and, should Multi-Sport have warned the players of the dangers of the game? The High Court answered both questions in the negative. The Court stressed that some sports involve 'obvious' risks. And indoor cricket can be dangerous; players and spectators can be injured. Kirby J (although dissenting) recognised that 'some risks are deemed "inherent" in particular activities. In some sports, for example, an element of risk is a feature of the game that may add to its essential enjoyment'. ${ }^{17}$

Justice Callinan commented:

Played as it was, with a semi-flexible ball and a bat with which to hit it as hard as possible, [indoor cricket] gives rise to an obvious risk that a ball might strike an eye. ... As I said in Agar $v$ Hyde, ${ }^{18}$ sports injuries and duties of care owed by those involved in sport simply cannot be approached in the same way as non-recreational or involuntary activities. What I have said is sufficient to dispose of the appellant's argument that the respondent should have warned the appellant of the risk, which was realised, of injury to his eyes. And, for the reasons that I have given, that of the ultimate objective of most sports, of the achievement of physical superiority or domination of one form or another by one person or team over another, promoters and organisers of sport will rarely, if ever,

$14 \quad$ Miller v Jackson [1977] EWCA Civ 6.

15 (2002) 208 CLR 460.

16 Woods v Multi-Sport Holdings Pty Ltd (2002) 208 CLR 460, 467 (Gleeson CJ).

$17 \quad$ Ibid 494.

$18 \quad$ (2000) 201 CLR 552. 
be obliged to warn prospective participants that they might be hurt if they choose to play the game. ${ }^{19}$

\section{TORT LAW REFORM IN AUSTRALIA}

In Australia, in the past, those who played contact sport rarely sought compensation for their injuries. It was generally believed that they had accepted the risk of injury by agreeing to compete. ${ }^{20}$ In recent times, a trend of litigiousness in sport has emerged..$^{21}$ In the late 1990s and early 2000s there was a growing fear among the Australian community that personal injury lawsuits were unduly hampering sporting activity. There was a widespread belief that the tort law system was supporting a culture of 'blame and claim', and that it was becoming too easy for plaintiffs to succeed. ${ }^{22}$ These perceptions were motivated by large court awards of damages resulting from recreational accidents. This was particularly so where the claimant would have known of the risk, should have exercised common sense and should have taken individual responsibility for their actions. ${ }^{23}$ Further, culminating with the collapse of insurance group HIH in 2002, Australia was believed to be in an 'insurance crisis'. This crisis was blamed on substantial increases in damages awards and rising legal expenses. Insurance premiums were high, and in some cases, insurers refused high risk liability insurance contracts. ${ }^{24}$

The increasing duties and expectations placed on those engaged in the sporting industry had made some recreational and sporting activities economically unfeasible. In 2002, Sports Industry Australia called for immediate reform, and drew attention to the plight of district cricket clubs in Victoria - they were informed that their public liability insurance premiums would rise by $93 \% .{ }^{25}$ Australian legislatures thought that they needed to 'swing the pendulum back' and rein in the more litigious claimants. ${ }^{26}{ }^{27}$ A National Expert Panel, chaired by Justice Ipp, was commissioned to recommend changes to the law of negligence. In response to the Ipp Report, legislation was enacted in all Australian jurisdictions. In Queensland it found its form in the Civil Liability Act 2003 ('CLA') and the Personal Injuries Proceedings Act 2002.

19 Woods v Multi-Sport Holdings Pty Ltd (2002) 208 CLR 460, 509 (Callinan J).

20 Dean Laing, 'Liability of Contact Sports Participants' (1993) Wisconsin Lawyer 12, 12.

21 See Natasha Schot, 'Negligent Liability in Sport' (2005) Sports Law eJournal 4.

22 Review of the Law of Negligence Final Report, Commonwealth of Australia, (September 2002) 25-6.

23 Paul de Jersey, 'A Review of the Civil Liabilities Act and Tort Reform in Queensland' (Paper presented at the Queensland Law Society Personal Injuries Conference, 29 June 2007) 2.

24 'Insurance Premiums and State Sporting Associations in Victoria - An Issue Escalating Out of Control' (2002) Executive Summary of the Report Prepared by VicSport and Presented to the Director, Sport and Recreation Victoria 1.

25 Andrew Davis, Australian Sport Faces Insurance Crisis (21 February 2002) Australian Canoeing $<$ http://www.canoe.org.au/?page=3343\&format $>$.

26 Natasha Schot, 'Negligent Liability in Sport' (2005) Sports Law eJournal 4.

27 This perception was disputed. A report commissioned by the Law Council of Australia and released 26 March 2006, National Trends in Personal Injury Litigation: Before and After 'Ipp' by Professor EW Wright, contended that 'contrary to widespread belief, litigation rates had not, generally, been increasing in the period leading to the Ipp Review'. (p 3) 
Major changes introduced by the CLA included:

- a $\$ 250,000$ cap on general damages;

- a cap on damages for past and future economic loss;

- no liability in cases where the injured person was engaged in criminal activity that contributed to the risk of injury;

- restricted claims where a person's intoxication contributed to their personal injury;

- no liability for failure to warn of obvious risks; and

- no liability for injuries arising from obvious risks of 'dangerous recreational activities'.

An 'obvious risk' is one that would have been patent or a matter of common knowledge, even if the likelihood of it occurring is low. ${ }^{28}$ An injured person is presumed to have been aware of this obvious risk, making it easier for the defence to succeed. However, the injured person can adduce evidence to show that he or she was not actually aware of the risk and thus rebut this presumption.

A 'dangerous recreational activity' is one that involves a significant risk of harm. ${ }^{29}$ Where the plaintiff was engaged in what can objectively be classified as a dangerous recreational activity, there is no need to establish that they were subjectively aware of the risk. ${ }^{30}$ This means that if a defendant can prove that there were inherent or obvious risks involved in the sport, they will not be liable, despite any negligence on their part causing the inherent or obvious risk to materialise.

These legislative reforms eliminated about $70 \%$ of Australian personal injury claims payments on business and household insurance policies. ${ }^{31}$ Some complained that this means a transfer of the financial burden of reckless conduct from the at-fault party (and its insurer) to the victim. Some also argue that the exemption of dangerous recreational enterprises from having to pay for injuries amounts to a subsidy of those businesses. It has, though, restored confidence to the organisers of sporting and recreational events that they can go ahead with their events without excessive exposure to the crippling costs, both reputational and financial, of legal pursuit.

\section{IS CRICKET A DANGEROUS RECREATIONAL ACTIVITY?}

Cricket is clearly a 'recreational activity'. It is an activity engaged in for enjoyment, relaxation and/or leisure. ${ }^{32}$ The question is, however, is it a dangerous recreational activity? ${ }^{33}$ The CLA defines a dangerous recreational activity as one which involves a 'significant degree of risk of physical harm' ${ }^{34}$

28 Civil Liability Act 2003 (Qld) s 13.

29 Ibid s 19(1).

30 Ibid s 19(2).

31 Tort Reform Institute Pty Ltd, Civil Liability Laws (10 November 2007)

$<$ http://www.tortreforminstitute.com.au/news.html\#cll >.

32 Civil Liability Act 2003 (Qld) s 18.

33 See generally David Thorpe and Pam Stewart, 'Not to be too pedantic.... But what exactly is a dangerous recreational activity?' (2006) 1 Australian and New Zealand Sports Law Journal 121, 127.

34 Ibid. 
'Significant' means more than trivial, but does not have to be 'likely'. ${ }^{35}$ Risk of physical harm may not be significant if, despite the potentially catastrophic nature of the harm, the risk is very slight. ${ }^{36}$

Particular activities, like cricket, can be segmented, for the purposes of assessing whether they are dangerous. In Fallas $v$ Mourlas, Ipp JA applied this segmentation principle to 'spotlighting', where participants shoot kangaroos at night with the aid of a spotlight. His Honour found that holding the spotlight was a separate activity from shooting, as was entering and leaving the vehicle used for the hunt. ${ }^{37}$ As we have already seen, there are some activities in cricket that are more dangerous than others. Batsman, for instance, have been injured more regularly than bowlers, or out fielders. So it would seem that a number of activities involved in the game, if not the entire game, could certainly be considered dangerous activities for the purposes of the CLA.

\section{‘OBVIOUS RISKS’ AND CRICKET}

Even if cricket, or particular activities engaged in by the players, is not regarded as a 'dangerous recreational activity', cricket still involves obvious risks. A 2002 Ministerial Media Statement addressed the proposed promulgation of the Civil Liability Act. In the Statement, former Queensland Premier Peter Beattie guaranteed that 'organisations will not be liable for injuries from obvious risks like a player being hit in the eye during a cricket match'. ${ }^{38}$

Common sense tells us that the risk of injury to batsmen and fielders, even umpires, during a cricket match is 'obvious'. As we have seen, injuries to those involved in a match are not infrequent and are sometimes fatal.

However, the position regarding other so-called 'freak accidents', where an errant cricket ball launched into the crowd or over a boundary fence causes injury, is less clear. Certainly, in modern cricket, the ball is hit into the crowd regularly. However, there have been no serious injuries reported from this practice. It could hardly be said that spectators, or innocent bystanders, would consider their proximity to a game of cricket to carry with it an 'obvious risk' of injury. However, we do recall unfortunate Bessie Stone in Bolton $v$ Stone. A risk of injury may be so 'un-obvious' and unlikely that it is not reasonably foreseeable, and thus will not found a claim in negligence in any event.

\section{DANGEROUS RECREATIONAL ACTIVITIES ARE THRILLING}

So, if we know them to be risky, why is it that we humans are so drawn to dangerous activities like cricket? It is the thrill of competition, competition being a natural drive in human beings. 'Over aeons of evolutionary time, it [competition] has left its mark on our psychological makeup ... the instinct for

35 Fallas v Mourlas [2006] NSWCA 32, [14], [16] (Ipp JA).

36 Falvo v Australian Oztag Sports Association [2006] NSWCA 17, [12] (Ipp J, with Hunt AJA and Adams JA agreeing).

37 Fallas v Mourlas [2006] NSWCA 32, [5] (Ipp JA).

38 Rod Welford, 'Common sense insurance proposals to give more certainty to Queensland' (Media Release, 3 December 2002), reproduced in Nicolee Dixon, Reform of Negligence Law: The Draft Civil Liability Bill 2002, (2003) Queensland Parliamentary Library, $<$ http://www.parliament.qld.gov.au/documents/explore/ResearchPublications/ResearchBriefs/2003/200301. $\mathrm{pdf}>36$. 
competition plays a role in every branch of human endeavour, from the writing of symphonies to new scientific discoveries' ${ }^{39}$

It is also that sporting activities offer a unifying influence in society and we take pleasure in its shared values and social cohesion. And some sports entertain because they are dangerous and risky. The defiance of risk can be admirable: the risky climbing of tall mountains can earn you peer respect, even a knighthood.

As Kitto J noted in Rootes $v$ Shelton, ${ }^{40}$ people have taken pleasure in engaging in risky games since long before the law of negligence was formulated. In Woods $v$ Multi-Sport Holdings, Callinan J observed that competition often involves risk:

\begin{abstract}
Almost all sport involves physical exertion, physical competition and a degree of physical domination, in one form or another, by one person or team over another: whether by running faster, jumping higher or further, scrummaging harder, throwing straighter and faster, or hitting a ball with better timing and more accuracy, or bowling faster. Even seemingly gentle sports will not be without risk: in table tennis, of being hit by the bat or ball, or in over-reaching for a shot.41
\end{abstract}

Dangerous sports attract both the participant and spectator. Sport's allure includes the adrenalin rush and camaraderie that comes from facing danger and overcoming it. Danger sports such as 'running with the bulls' at Pamplona, bungee jumping and parachuting, rock climbing and mountain biking, and facing devastating fast bowling in cricket, produce pain and privation, but also pleasure and release; and honour. We search out and admire the brave risk-takers in many areas of life. Dangerous sport provides a higher level of entertainment and excitement and follows the mantra that 'life shouldn't be too dull. Risk does give you a sense of excitement, of being alive' ${ }^{42}$

The law should stay well back from regulating every risky situation and underwriting every recreational injury, to avoid cutting too deeply into the benefits of societal cohesion, noble physical attributes and wellbeing that dangerous recreational sports provide. Society should tolerate, perhaps encourage the dangerous sports, for their benefits vastly outweigh their costs.

\title{
FREE WILL AND LIBERTY
}

The common law has been inclined to preserve individualist rights. So did Canon Law and Roman Law, from whence came the doctrine of volenti non fit injuria - 'to a willing person, no actionable injury is done'. ${ }^{43}$ This is a policy of social maturity. One should accept responsibility for one's actions and preserve liberty of action.

The House of Lords in Tomlinson $v$ Congleton Borough Councill4 preferred free will to accept obvious risks over the making of policies requiring people to take steps to protect others against obvious risks.

39 Shane Gilchrist, 'Survival of the Fittest', Otago Daily Times (online), 22 October 2011

$<$ http://www.odt.co.nz/print/183357?page $=0 \% 2 \mathrm{C} 2>$.

$40 \quad$ (1967) 116 CLR 383, 387.

41 Woods v Multi-Sport Holdings Pty Ltd (2002) 208 CLR 460, 509 (Callinan J).

42 Gretel H Schueller, ‘Thrill or Chill’ (2000) 166(2236) New Scientist $20<\mathrm{http}: / /$ find.galegroup.com/>.

43 Volenti is where a plaintiff accepts a risk. It can be distinguished from 'consent' - which can prevent some torts arising at all. For example, consent to a medical operation prevents an invasive operation from being a trespass to the person.

44 [2003] UKHL 47. The plaintiff dived into a lake in an old sand quarry to cool off. He struck his head on the sandy bottom, broke his neck and became a tetraplegic. 
We favour individual liberty of action, said Lord Hoffmann, in a case concerning a young person who broke his neck in a badly-executed dive into a lake:45

I think that there is an important question of freedom at stake. ...

It is of course understandable that organisations like the Royal Society for the Prevention of Accidents should favour policies which require people to be prevented from taking risks. Their function is to prevent accidents and that is one way of doing so. But they do not have to consider the cost, not only in money but also in deprivation of liberty, which such restrictions entail. ... [T]he balance between risk on the one hand and individual autonomy on the other is not a matter of expert opinion. It is a judgment which the courts must make and which in England reflects the individualist values of the common law.

45 Ibid [46]-[47]. 